\title{
A new species of Euclea (Ebenaceae) from ultramafic soils in Sek- hukhuneland, South Africa, with notes on its ecology
}

\author{
E. RETIEF*, S.J. SIEBERT** and A.E. VAN WYK***
}

Keywords: Ebenaceae, Euclea Murray, ecology, new species, Sekhukhuneland, South Africa, summer rainfall region, taxonomy

\author{
ABSTRACT
}

Euclea sekhukhuniensis Retief, Siebert \& A.E.van Wyk, a new species with a restricted range in Sekhukhuneland, South Africa, is described, illustrated and compared with other members of the genus. It is a gregarious geoxylic suffrutex forming large, much-branched colonies. The species is closely related to the small tree/shrub $E$. linearis Zeyh. ex Hiern from which it can be distinguished by its larger fruits, broader leaves and exclusively suffrutex growth form. Geographical range and habitat preference also differ between the two taxa. E. sekhukhuniensis is endemic to the Sekhukhuneland Centre of Plant Endemism. where it is confined to the calcareous, heavy-metal soils of the Steelpoort River Valley.

\section{INTRODUCTION}

Areas underlain by ultramafic rocks in Mpumalanga and Limpopo, and adjacent parts of Zimbabwe, contain a rich but still poorly studied flora. Examples of taxa newly described from these substrates include Searsia pygmaea (Anacardiaceae) from serpentinite near Barberton (Moffett 1999), Rhoicissus sekhukhuniensis (Vitaceae) from norite/pyroxenite near Steelpoort (Retief et al. 2001 ) and Peristrophe serpenticola from the Great Dyke (Balkwill \& Campbell-Young 2001). Recent vegetation surveys of the ultramafic rocks of the Sekhukhuneland Centre of Plant Endemism (SCPE), a microregional centre of plant endemism and diversity (Van Wyk \& Smith 2001), have revealed many undescribed plant taxa endemic to this phytogeographical region (Siebert et al. 2001). Future floristic surveys in this under-collected region are likely to reveal many new distribution records and possibly further new taxa. Other species known to be endemic to the SCPE include Raphionacme villicorona (Apocynaceae), Asparagus sekukuniensis (Asparagaceae), Acacia ormocarpoides, A. sekhukhuniensis, Elephantorrhiza praetermissa (Fabaceae), Euphorbia harnardii, E. sekukuniensis (Euphorbiaceae), Gladiolus sekhukhuniensis (Iridaceae), Plectranthus porcatus, P. venteri (Lamiaceae), Hibiscus coddii subsp. barnardii (Malvaceae), Searsia hatophylla, S. sekhukhuniensis (Anacardiaceae), Zantedeschia jucunda and $Z$. pentlandii (Araceae).

The SCPE lies to the west of the northeastern section of the Great Escarpment of South Africa and is characterized by a heterogeneous geology, topography and climate (Van Wyk \& Smith 2001). The core area of the Centre straddles the border of Mpumalanga and Limpopo, around the towns of Burgersfort, Mecklenburg, Roossenekal, Schoonoord and Steelpoort. The SCPE is best demarcated in geological terms as the

\footnotetext{
- National Herbarium. South African National Biodiversity Institute. Private Bag X101.0001 Pretoria.

* A.P. Goossens Herbarium. School of Environmental Sciences and Development. North-West University, Private Bag X6001, 2520 Potchefstroom. South Africa.

*** H.G.W.J. Schweickerdt Herbarium. Department of Botany. University of Pretoria, 0002 Pretoria.

MS. received: 2007-04-05.
}

large, far-eastern outcrop of ultramafic rocks belonging to the Rustenburg Layered Suite of the eastern Bushveld Complex. These rocks are mainly norite, pyroxenite, anorthosite and ferrogabbro, with localized intrusions of magnetitite and chromitite (Viljoen \& Schürman 1998). Topographically the SCPE is a mountainous area bordered by the high ground of the Drakensberg Escarpment in the north and east, the Highveld Escarpment to the south and the Springbok Flats to the west. It lies adjacent to and west of the Wolkberg (Van Wyk \& Smith 2001) and Lydenburg (Schmidt et al. 2002) Centres of Plant Endemism, both part of the northeastern Drakensberg Escarpment.

Previously a Euclea taxon with a suffrutex habit and narrow elliptical leaves from Sekhukhuneland was tentatively considered a hybrid between $E$. linearis Zeyh. ex Hiern and E. crispa (Thunb.) Gürke subsp. crispa (De Winter 1963) - a suspicion based on the overlapping distribution ranges of these two species in Sekhukhuneland. However, subsequent detailed field work and comparative morphological studies have shown the putative hybrid to be a distinct new species, closely related to $E$. linearis and endemic to the ultramafic soils of the SCPE. The new species is here described as Euclea sekhukhuniensis Retief, Siebert \& A.E.van Wyk. This is the second Euclea species, after E. dewinteri Retief (Retief 1986), an endemic of the Wolkberg Centre of Plant Endemism, that is strictly confined to the larger northeastern Drakensberg Escarpment.

The genus Euclea comprises \pm 20 species, confined to Africa, Arabia, Socotra and the Comoro Islands, with its centre of diversity in southern Africa (Dyer 1975; Bredenkamp 2000). In addition to E. sekhukhuniensis, seven species and infraspecific taxa occur in the SCPE. namely E. crispa subsp. crispa, E. divinorum Hiern, $E$. linearis, E. natalensis A.DC. subsp. angustifolia F.White, E. daphnoides Hiem, E. schimperi A.DC. and E. undulara Thunb. (Table 1). However, the list is provisional, for the region is still poorly sampled. All these taxa are evergreen shrubs or trees, except E. sekhukhuniensis, which is an evergreen geoxylic suffrutex. A form of E. crispa (White 1977) along the northeastern Drakensberg Escarpment (but not entering the SCPE) exhibits the same growth form as E. sekhukhuniensis. 
MATERIALS AND METHODS

Euclea specimens housed in the National Herbarium (PRE), Pretoria, and H.G.W.J. Schweickerdt Herbarium (PRU), University of Pretoria (acronyms as in Holmgren et al. 1990) were examined to gather data on morphology, phenology and distribution.

Ecological data are based on extensive field observations of Euclea linearis and E. sekhukhuniensis in the SCPE (Siebert et al. 2002a, b). Specimens were sampled from the region during all seasons, environmental factors were noted and plant communities identified. The specimens Siebert 935, 937 and Van Wyk \& Siebert 13060 were identified as typical E. linearis for comparing ecological traits with E. sekhukhuniensis. Plant material and soil samples were taken at ten sites, five each dominated by either $E$. linearis or $E$. sekhukhuniensis. Voucher specimens were taken from these sites; Siebert 937 represents E. linearis and Siebert 938 represents $E$. sekhukhuniensis (specimens kept at PRU). Soil analysis was done with X-Ray Fluorescence (XRF) Spectrometry, Department of Geology, University of Pretoria and plant analysis with Atomic Absorption Spectrophotometry (AAS) and Inductively Coupled Plasma-Mass Spectrometry (ICP-MS) at the Department of Soil, Climate and Water in Pretoria.

\section{TAXONOMY}

Euclea sekhukhuniensis Retief, Siebert \& A.E.van Wyk, sp. nov., E. lineari Zeyh. ex Hiern similis sed habitu (suffrutex, non frutex vel arbor parva), forma foliorum elliptica recta, non anguste elliptica nec lineari nec falcata, fructu globoso maiore $( \pm 9 \mathrm{~mm}$, non $\pm 5.5 \mathrm{~mm}$ diametro) differt.

TYPE.-Mpumalanga, 2430 (Pilgrim's Rest): 10 km NW of Maartenshoop, (-CC), Codd 8796 (PRE, holo.; $\mathrm{K}$, iso.). Figure 1 .

Euclea linearis Zeyh. ex Hiern sensu De Winter: 94 (1963) quoad Codd 8796.

Woody suffrutex, $0.3-1.5 \mathrm{~m}$ high, forming large colonies of much-branched clones $\pm 5 \mathrm{~m}$ diam. Plants evergreen, dioecious. Branches ascending, slender and glabrous, except for a rust-brown granular exudate on

TABLE 1.-Distribution of seven species of Euclea according to quarter-degree grid squares of SCPE

\begin{tabular}{|c|c|c|c|c|c|c|c|c|c|c|c|c|}
\hline $\begin{array}{l}\text { Euclea species/infraspecific } \\
\qquad \begin{array}{l}\text { taxa } \\
\end{array}\end{array}$ & ָั) & শิ & 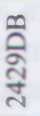 & ปิ & ঠ্ড & 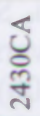 & లో & 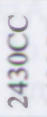 & 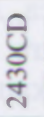 & $\begin{array}{l}\text { mิ } \\
\text { ปิ } \\
\text { ฟิ }\end{array}$ & 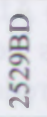 & 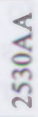 \\
\hline E. crispa subsp. crispa & & • & • & - & 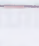 & - & $\cdot$ & $\cdot$ & $\cdot$ & $\cdot$ & - & $\cdot$ \\
\hline E. divinorum & & - & - & & - & - & - & - & - & & & \\
\hline E. linearis & & - & & - & - & - & - & - & - & - & & \\
\hline $\begin{array}{l}\text { E. natalensis subsp. angus- } \\
\text { tifolia }\end{array}$ & & & & & - & - & & & - & - & - & \\
\hline $\begin{array}{l}\text { E. schimperi var. daphnoi- } \\
\text { des }\end{array}$ & & & & & - & - & & - & & & & \\
\hline E. schimperi var. schimperi & & - & & & - & & & & & & & \\
\hline E. sekhukhuniensis & & - & & & & - & - & - & & - & & \\
\hline E. unchulata & - & - & - & - & - & - & - & - & - & - & & \\
\hline Total & 1 & 6 & 3 & 3 & 6 & 7 & 5 & 6 & 5 & 5 & 2 & \\
\hline
\end{tabular}

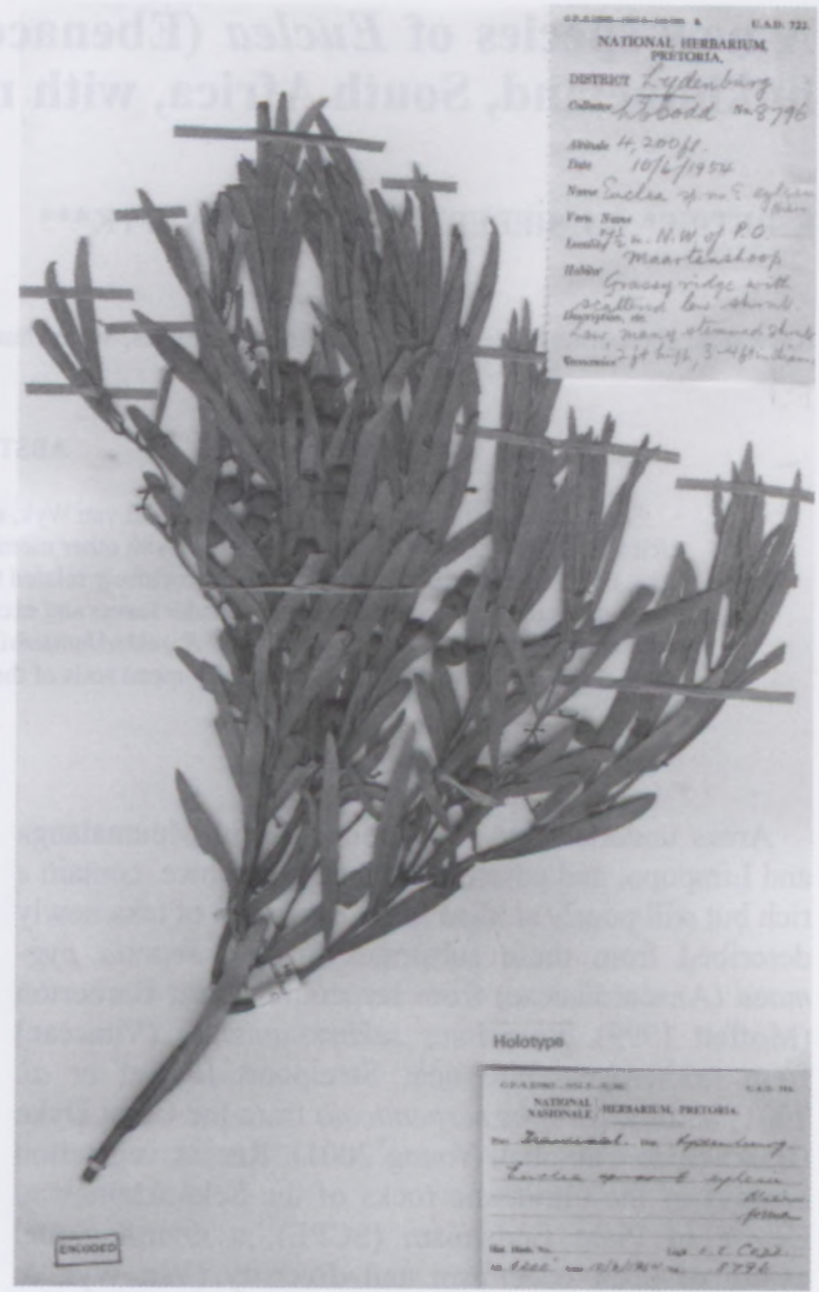

FIGURE 1.-Euclea sekhukhuniensis, Codd 8796, holo. (PRE).

young growth; bark grey on older stems. Leaves simple, subopposite, subsessile; blade oblanceolate-elliptic, straight, $25-75(-90) \times 4-8(-10) \mathrm{mm}$, glabrous, leathery and smooth, except for a rust-brown granular exudate on younger leaves, usually yellowish green above and pale green below; base tapering into a very short petiole ( 1 $\mathrm{mm}$ ), apex acute to rounded, margin entire, main vein and principal lateral veins prominent above and below. Inflorescences axillary, few-flowered, clusters or short spikes. Flowers regular. Male flowers: calyx 4-lobed, \pm 3 $\mathrm{mm}$ long; corolla campanulate, deeply 4-lobed, $\pm 5 \mathrm{~mm}$ long, pale cream-coloured to pinkish white, appressed hairy on back; stamens 8 , narrowly ovate, $\pm 3 \mathrm{~mm}$ long, anther thecae pubescent on outer surface. Female flowers: calyx not accrescent, persistent in fruit, 4-lobed, \pm $2 \mathrm{~mm}$ long; corolla 4-lobed, $\pm 4 \mathrm{~mm}$ long, green, lobes appressed hairy on back; ovary hairy, borne on a fimbriate, fleshy disc; styles 2. Fruit an indehiscent, globose berry, $\pm 9 \times 10 \times 8 \mathrm{~mm}$, densely appressed hairy; young fruits green, ripening through brownish red to purplish black. Flowering time: October to January. Fruiting time: November to February. Figure 2.

Diagnostic characters: members of Euclea can be divided into two groups (De Winter 1963): 1, species with the corolla shallowly lobed at the apex; and 2, species with the corolla cleft at least halfway down or more. All the Euclea taxa occurring in the SCPE belong to the latter group. E. sekhukhuniensis and E. linearis are dis- 

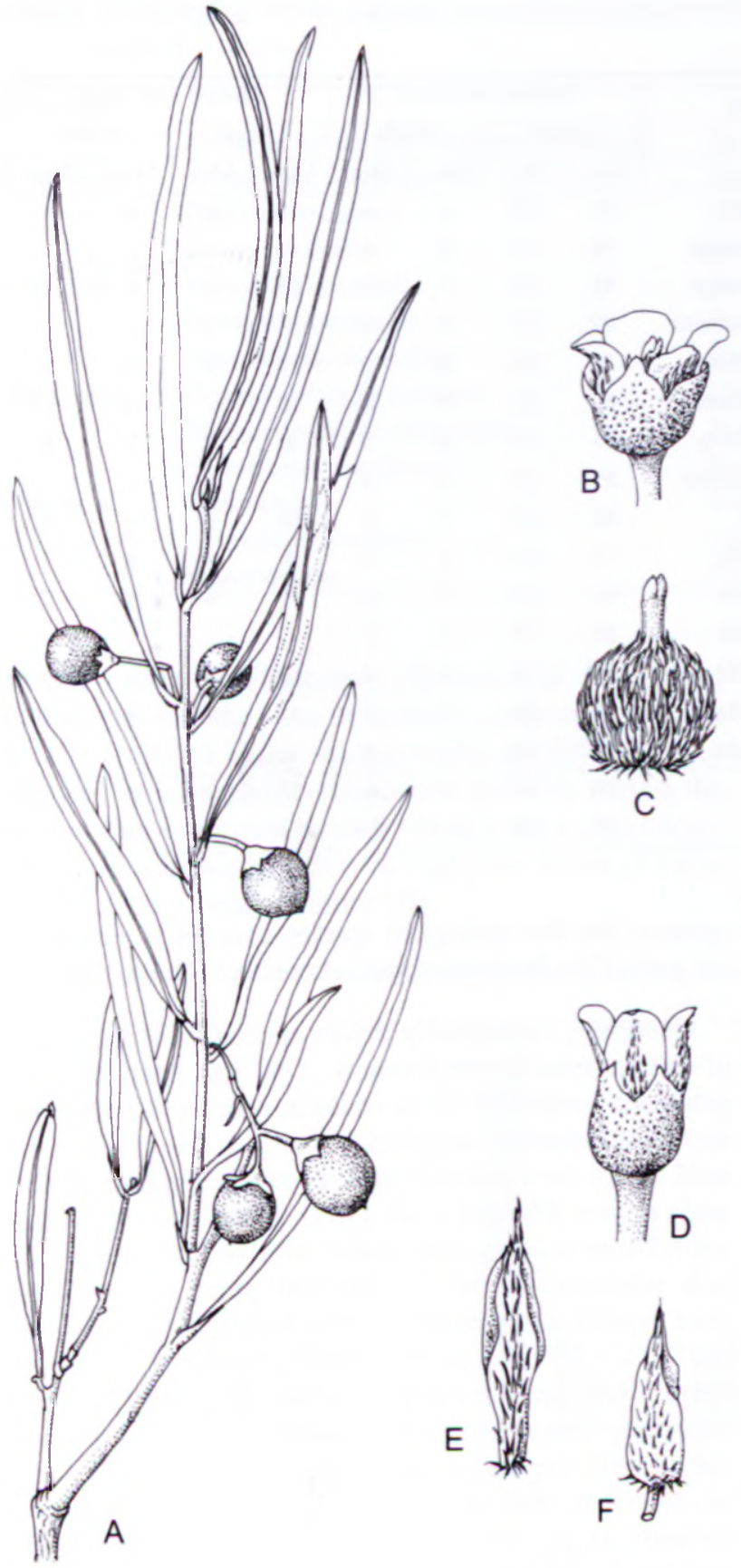

FIGURE 2 - Euclea sekhukhuniensis. Plant Specialist Group 4 (PRE). A, fruiting branch, $\times 0.75 ; \mathrm{B}$, female flower, $\times 3.8 ; \mathrm{C}$, gynoecium. $\times 7.5 ; \mathrm{D}$, male flower, $\times 3.8 ; \mathrm{E}$. stamen of outer row, $\times$ 7.5; F stamen of inner row, $\times$ 7.5. Artist: $G$. Condy

tinguished from the others by their narrowly oblanceolate-elliptic to linear or linear-falcate leaves and young leaves and twigs that are covered with a granular, rustbrown exudate. E. sekhukhuniensis is most closely related to $E$. linearis; however, E. sekhukhuniensis is a gregarious, evergreen geoxylic suffrutex (White 1977), whereas $E$. linearis is a shrub or tree up to $5 \mathrm{~m}$ high. Leaves of $E$. sekhukhuniensis are straight, broader and longer than the sickle-shaped leaves of $E$. linearis and its fruits are larger than those of $E$. linearis (Table 2).

Conservation status: Euclea sekhukhuniensis has a restricted geographical range within which it is locally fairly common (Figure 3). However, some of its habitat is under immediate threat of rapid urbanization as a result of increased mining activities in the greater
Steelpoort River Valley and the construction of the De Hoop Dam on the Steelpoort River. E. sekhukhuniensis is not formally protected in any conservation area. Populations of this species should therefore be closely monitored and a Red Data List assessment of this species prioritized. Its conservation value is considered relatively high, as it could possibly be used in the rehabilitation of mine dumps due to its internal mechanism of excluding heavy metals.

Ecology and speciation: both Euclea sekhukhuniensis and $E$. linearis occur on vegetation anomalies-sparsely vegetated soils that are mineralized (Table 3 ). This phenomenon is well reported for populations of $E$. linearis in wooded grassland on the serpentinites of the Great Dyke in Zimbabwe (Wild 1965). A distant outlier of what has been identified as $E$. linearis is also found on grassy ridges in fynbos in a limited area in the Calvinia and Vanrhynsdorp region of the Western Cape, where it grows on nutrient-poor soils derived from sandstone of the Table Mountain Group (White 1983). However, the identity of these plants requires verification. In the mountainous regions of the northern provinces of South Africa, E. linearis grows on rocky outcrops and in dry woodlands on slopes and in valleys of serpentenite (Barberton Supergroup) in the Barberton region, acidic sandstone (Waterberg Group) of the Waterberg of Limpopo, and quartzites (Black Reef Formation) along the northeastern Drakensberg Escarpment (White 1983). Thus, it appears that $E$. linearis tends to colonize habitats with harsh soil conditions in mountainous regions (acidic, nutrient poor and/or rich in heavy metals).

Euclea sekhukhuniensis appears to be an example of incipient sympatric speciation due to ecological interactions in a new habitat in which restricted gene flow has evolved through selective reproduction between individuals of $E$. linearis that are adapted to a specific ultramafic substrate. This speculation is supported by the work of Alados et al. (1999), which demonstrates that asymmetry and within-plant variance were higher between specimens of the same species in the contact zone between ultramafic and normal soils. In the SCPE, habitat preference has resulted in the two Euclea species

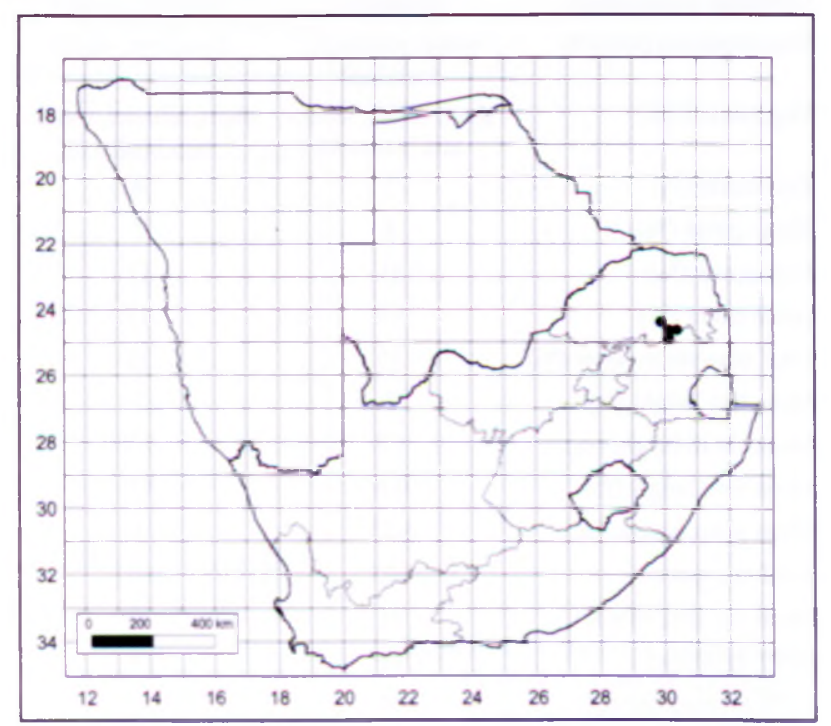

FIGURE 3.-Knowt distribution of Euclea sekhukhuniensis 
TABLE 2.-Leaf and fruit measurements of 15 Euclea sekhukhuniensis specimens and only results of 30 randomly selected specimens of $E$. linearis from Mpumalanga and Limpopo (all in PRE)

\begin{tabular}{|c|c|c|c|c|c|c|c|c|c|c|c|}
\hline \multirow[t]{3}{*}{ No. } & \multirow[t]{3}{*}{ Collector no., herbarium } & \multirow[t]{3}{*}{ Grid } & \multirow[t]{3}{*}{ Locality } & \multicolumn{4}{|c|}{ Mature leaf $(\mathrm{mm})$} & \multicolumn{4}{|c|}{ Mature fruit (mm) } \\
\hline & & & & \multicolumn{2}{|c|}{ Length } & \multicolumn{2}{|c|}{ Width } & \multicolumn{2}{|c|}{ Length } & \multicolumn{2}{|c|}{ Width } \\
\hline & & & & Max. & Min. & Max. & Min. & Max. & Min. & Max. & Min. \\
\hline 1. & Herman 793 (PRE) & $2430 \mathrm{CB}$ & Burgersfort & 55 & 27 & 6 & 4 & 11 & 9 & 9 & 8 \\
\hline 2. & Van Wyk, Siebert \& Retief 13204 (PRU) & $2430 \mathrm{CC}$ & Frischgewaagd & 76 & 19 & 6 & 4 & - & - & - & - \\
\hline 3. & Siebert $411(\mathrm{PRU})$ & $2430 \mathrm{CC}$ & Frischgewaagd & 81 & 22 & 7 & 4 & 10 & 9 & 9 & 8 \\
\hline 4. & Barnard \& Mogg 1031 (PRE) & 2429BD & Leolo Mountains & 89 & 31 & 9 & 5 & - & - & - & - \\
\hline 5. & Wright G14 (PRE) & $2430 \mathrm{CA}$ & Maandagshoek & 80 & 26 & 8 & 5 & 11 & 9 & 10 & 9 \\
\hline 6. & Kritzinger 138(PRE) & $2430 \mathrm{CA}$ & Maandagshoek & 80 & 22 & 10 & 6 & 10 & - & 10 & - \\
\hline 7. & Codd 8796 (PRE) & $2430 \mathrm{CC}$ & Maartenshoop & 81 & 39 & 10 & 5 & 8 & 7 & 7 & 6 \\
\hline 8. & Siebert $938(\mathrm{PRU})$ & $2430 \mathrm{CC}$ & Olifantspoortjie & 85 & 19 & 6 & 3 & - & - & - & - \\
\hline 9. & Van Wyk 13299 (PRU) & $2430 \mathrm{CC}$ & Steelpoort & 62 & 21 & 7 & 5 & 10 & 9 & 9 & 8 \\
\hline 10. & Van Wyk 13035 (PRU) & $2430 \mathrm{CC}$ & Thomecliffe & 75 & 23 & 7 & 3 & 9 & 8 & 8 & 7 \\
\hline 11. & Van Wyk $13036(\mathrm{PRU})$ & $2430 \mathrm{CC}$ & Thomecliffe & 82 & 20 & 7 & 4 & 12 & 9 & 10 & 9 \\
\hline 12. & Van Wyk \& Siebert 13312 (PRU) & $2430 \mathrm{CC}$ & Thomecliffe & 60 & 19 & 7 & 2 & - & - & - & - \\
\hline 13. & Van Wyk \& Siebert 13313 (PRU) & $2430 \mathrm{CC}$ & Thomecliffe & 76 & 23 & 9 & 4 & 10 & 8 & 9 & 7 \\
\hline 14. & Plant Specialist Group 4 (PRE) & $2430 \mathrm{CC}$ & Thomecliffe & 86 & 22 & 7 & 4 & 11 & 8 & 8 & 7 \\
\hline 15. & Siebert $934(\mathrm{PRU})$ & $2430 \mathrm{CC}$ & Tweefontein & 68 & 18 & 12 & 5 & - & - & - & - \\
\hline \multicolumn{4}{|c|}{ Euclea sekhukhuniensis mean measurement ( 15 specimens) } & 76 & 23 & 8 & 4 & 10 & 8 & 9 & 8 \\
\hline \multicolumn{4}{|c|}{ Euclea linearis mean measurement (30 specimens) } & 52 & 28 & 2.5 & 1.8 & 5.9 & - & 5.4 & - \\
\hline
\end{tabular}

now growing in specific, but different habitats in association with specific plant species (Tables 3,4). According to Dieckmann \& Doebeli (1999), theoretical evidence suggests a prominent role for ecologically driven speciation in sympatry. Hence, the present study supports the

TABLE 3.-Environmental, structural and floristic characteristics unique to plant communities dominated by either Euclea sekhukhuniensis or E. linearis in Steelpoort River Valley

\begin{tabular}{|c|c|c|}
\hline Characteristics & E. sekhukhuniensis & E. linearis \\
\hline Slope $\left({ }^{\circ}\right)$ & $4(0-9)$ & $3(1-5)$ \\
\hline Aspect & $\mathrm{S}, \mathrm{N}$ & $\mathrm{S}, \mathrm{W}$ \\
\hline Rock cover $(\%)$ & $45(25-70)$ & $40(10-80)$ \\
\hline Rock size (mm) & $465(100-1500)$ & $225(50-500)$ \\
\hline Soil type & Glenrosa, Valsrivier & $\begin{array}{c}\text { Bonheim, Steendal, } \\
\text { Valsrivier }\end{array}$ \\
\hline Geology & $\begin{array}{l}\text { pyroxenite, norite, } \\
\text { magnetite }\end{array}$ & $\begin{array}{c}\text { alluvium, pyroxenite } \\
\text { gabbro }\end{array}$ \\
\hline Chemical composition & calcareous & brackish (sodic) \\
\hline Topographical position & $\begin{array}{l}\text { scarp, midslope. } \\
\text { footslope }\end{array}$ & footslope, valley \\
\hline Vegetation type & $\begin{array}{l}\text { short, rocky, moun- } \\
\text { tain bushveld }\end{array}$ & $\begin{array}{l}\text { short, alluvial, moun } \\
\text { tain bushveld }\end{array}$ \\
\hline Tree cover $(\%)$ & 3 & 4 \\
\hline Shrub cover $(\%)$ & 8 & 7 \\
\hline Forb cover $(\%)$ & 11 & 11 \\
\hline Grass cover $(\%)$ & 13 & 17 \\
\hline Total vegetation cover $(\%)$ & 35 & 39 \\
\hline Mean tree height $(\mathrm{m})$ & 3 & 3 \\
\hline Mean shrub height (m) & 1.7 & 1.8 \\
\hline Mean forb height (m) & 0.6 & 0.6 \\
\hline Mean grass height $(\mathrm{m})$ & 1.25 & 1 \\
\hline Total no. species & 105 & 96 \\
\hline Mean no. species/site & 44 & 42 \\
\hline SCPE endemics & 14 & 14 \\
\hline SCPE near-endemics & 9 & 10 \\
\hline Red Data List taxa & 4 & 4 \\
\hline
\end{tabular}

opinion that the ecological species concept is an essential part of the biological species concept (Grant 1992).

Generally, ecologically driven speciation is the result of habitat-specific preferences. This has been investigated and confirmed for an endemic species of Impatiens and its widespread congener (Chung \& Kang 1996), as well as for two endemic species of Dicerandra of the same region (Menges et al. 1999). In the case of Euclea sekhukhuniensis, an open niche with an anomalous Carich substrate $(14.68 \%=146800 \mathrm{ppm})$ in an otherwise typical environment of brackish soils rich in $\mathrm{Mg}$ $(19.97 \%=199700 \mathrm{ppm})$, probably favoured speciation (Figure 4A). Similar trends have been perceived between especially limestone (Ca-rich) and sandstone, once again for an endemic and its widespread congener (Walck et al. 1999), as well as two endemics of the same region (Mustart et al. 1994). Like limestone, the soils inhabited by $E$. sekhukhuniensis are Ca-rich $(1.95 \mathrm{Ca}: 1 \mathrm{Mg})$, more than double that of the soil substrate of $E$. linearis (Figure 4A). Furthermore, soils in which $E$. linearis grows have higher concentrations of total $\mathrm{Cr}$ and $\mathrm{Ni}$ (typical elements of serpentinite) (Figure 4B), with high $\mathrm{Fe}, \mathrm{Si}$ and $\mathrm{Mg}$ levels (1Mg:0.34Ca) (Figure 4A), and it accumulates relatively high concentrations of $\mathrm{Al}$ and $\mathrm{Fe}$ in its roots (Figure 5A). E. sekhukhuniensis accumulates lower levels of $\mathrm{Fe}$ in its roots, but with higher concentrations of $\mathrm{Cr}$ and $\mathrm{Ni}$ than E. linearis, although these levels are very low and not regarded as hyperaccumulation (Figure 5A). Overall, it seems that E. sekhukhuniensis is the better excluder of heavy metals, when considering the high concentrations of metals in the associated soil.

It is suggested that Euclea sekhukhuniensis was an ecotype of and has developed from $E$. linearis as a result of the genetic properties of the latter to adapt to and colonize ultramafic soils such as those derived from serpentinite (Wild 1974). It is hypothesized that E. sekhukhumiensis is a 'soil-adapted' neo-endemic which speciated 
TABLE 4.-Prominent taxa recorded for communities dominated by either Euclea sekhukhuniensis or E. linearis in Steelpoort River Valley (Siebert et al. 2002b)

\begin{tabular}{|c|c|c|c|}
\hline \multirow[t]{2}{*}{ Life forms } & \multicolumn{3}{|c|}{ Species dominant in: } \\
\hline & Euclea sekhukhuniensis dominated community & Euclea linearis dominated community & Both communities \\
\hline \multirow[t]{3}{*}{ Grass layer } & Heteropogon contortus & Andropogon chinensis & Brachiaria serrata \\
\hline & Tristachya leucothrix & Fingerhuthia africana & Diheteropogon amplectens \\
\hline & Setaria sphacelata & Loudetia simplex & Themeda triandra \\
\hline \multirow[t]{3}{*}{ Forb layer } & Rhynchosia spectabilis & Dicoma gerrardii & Berkheya insignis \\
\hline & Orthosiphon fruticosus & Petalidium oblongifolium & Gnidia caffra \\
\hline & Jamesbrittenia macrantha & Rhynchosia komatiensis & Phyllanthus glaucophyllus \\
\hline \multirow[t]{3}{*}{ Shrub layer } & Elephantorrhiza praetermissa & Grewia vernicosa & Brachylaena ilicifolia \\
\hline & Diospyros lycioides subsp. nitens & Searsia keetii & Tinnea rhodesiana \\
\hline & Hippobromus pauciflorus & Searsia wilmsii & Vitex obovata subsp. wilmsii \\
\hline \multirow[t]{3}{*}{ Tree layer } & Catha edulis & Bolusanthus speciosus & Acacia caffra \\
\hline & Cussonia transvaalensis & Combretum hereroense & Euclea crispa subsp. crispa \\
\hline & Faurea saligna & Protea caffra & Lydenburgia cassinoides \\
\hline
\end{tabular}

recently, after the Pleistocene (Reeves et al. 1983), and has not yet had the time or routes to migrate out of the Steelpoort River Valley. However, it is doubtful whether this will ever happen, as the species probably prefers the open niches of ultramafic soils where it has a physiological mechanism associated with high plant levels of $\mathrm{Ca}$ to tolerate heavy metals (Figure 5B).
Specific epithet and common names: the specific epithet refers to the geographical area where the species is endemic. Sekhukhuneland is traditionally inhabited by the Pedi (Mönnig 1967) and is currently under the reign of K.K. Sekhukhune (Paton 1998). Common names for the taxon include moshigwane (Northern-Sotho), Steelpoort guarri (English) and Steelpoortghwarrie (Afrikaans).
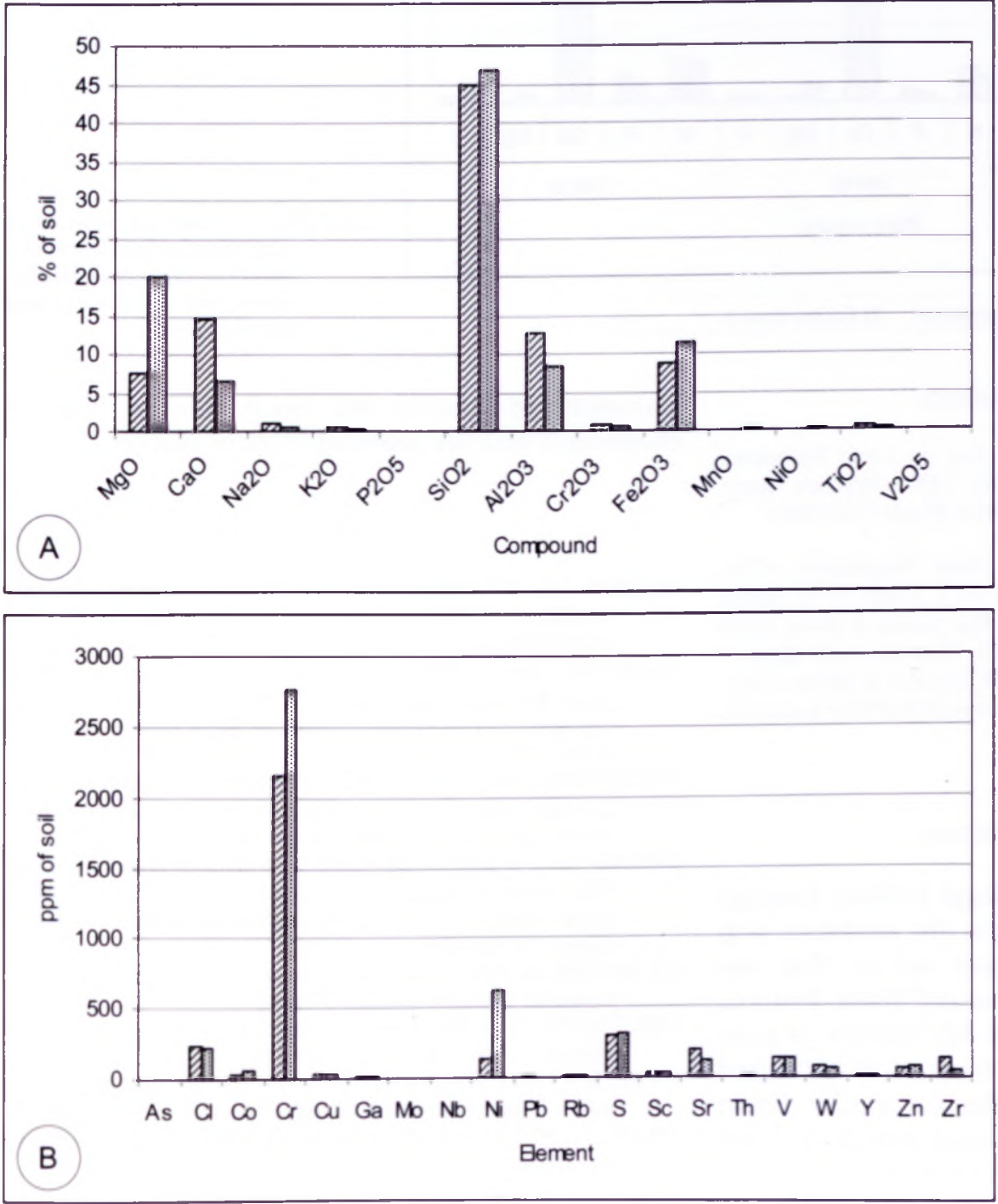

FIGURE 4.-Chemical analyses of five soil samples collected from root zone ( $300 \mathrm{~mm}$ deep) for each of Euclea sekhukhuniensis and $E$. linearis. 

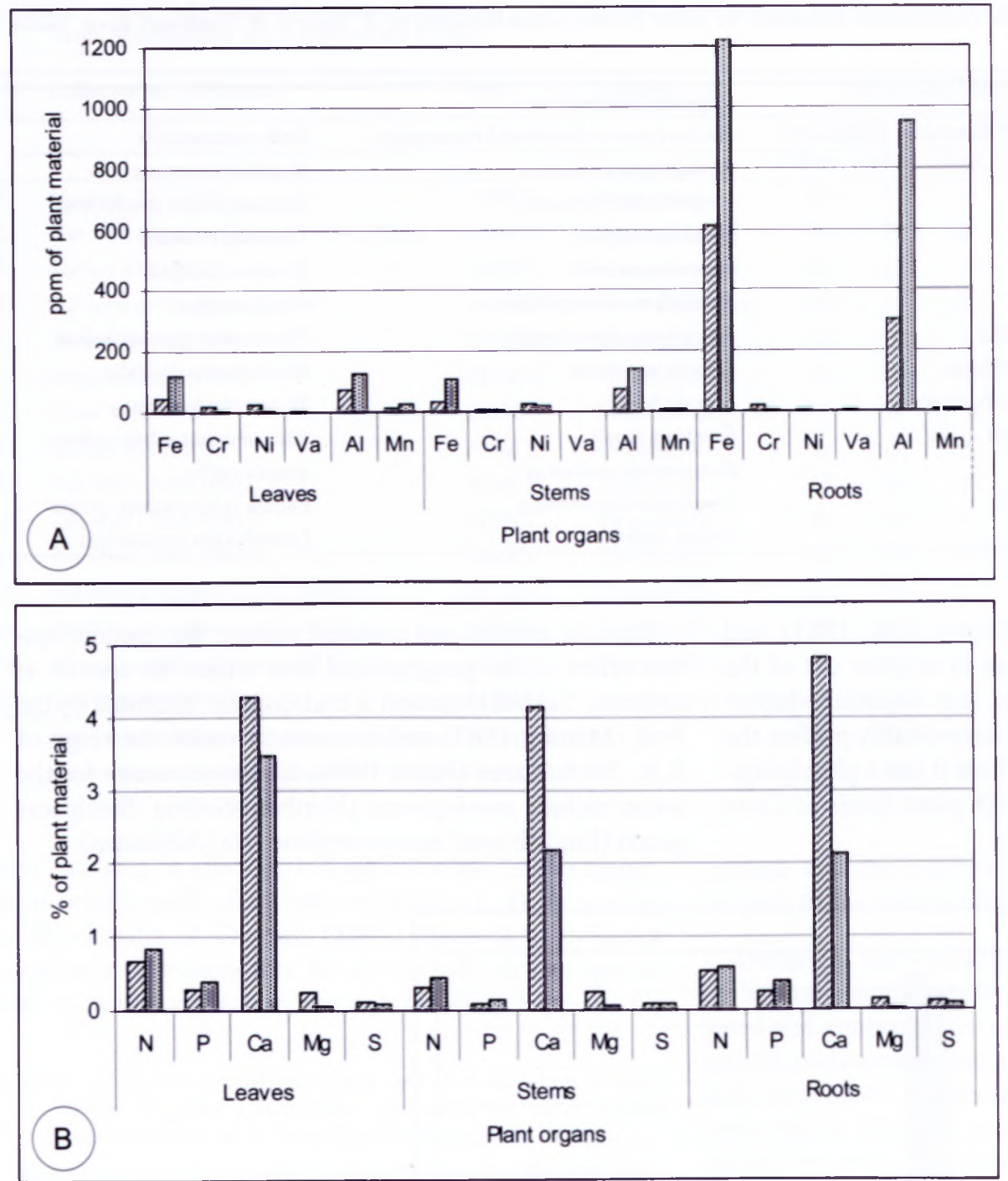

E Euclea sekhukhuniensis

- Euclea linearis
FIGURE 5.-Chemical analyses of plant material from five individuals each of Eucleasekhukhuniensis and $E$. linearis (young and old growth)

\section{SPECIMENS EXAMINED}

LIMPOPO_-2429 (Zebediela): Het Fort on Leolo Mountains, (-BD), Barnard \& Mogg 1031 (PRE). 2430 (Pilgrim's Rest): Maandagshoek. (-CA), Kritzinger 138 (PRU), Wright GI4 (PRE).

MPUMALANGA-2430 (Pilgrim's Rest): Burgersfort, (-CB), Herman 793 (PRE); Maartenshoop. (-CC), Codd 8796 (PRE); Frischgewaagd, (-CC), Siebert 411, Van Wyk, Siebert \& Retief 13204 (PRU): Thornecliffe Chrome Mine, (-CC). Plant Specialist Group 4 (PRE), Siebert 934, Van Wyk 13035, 13036, Van Wyk \& Siebert 13312. 13313 (PRU); Olifantspoortjie, (-CC), Siebert 938 (PRU); Steelpoort, (-CC), Van Wyk 13299 (PRU).

\section{ACKNOWLEDGEMENTS}

The authors are indebted to Maggi Loubser, Geology Department, University of Pretoria, for assistance with XRF analysis of the soil samples and to Nina van Vliet, Department of Soil, Climate and Water, Pretoria, for assistance with AAS and ICP-MS analysis of plant material. Francois du Randt of Burgersfort is thanked for collecting fertile material of the new species. Emsie du Plessis and Hugh Glen of the South African National Biodiversity Institute are respectively thanked for proofreading the manuscript and for translating the diagnosis into Latin. The Andrew W. Mellon Foundation,
University of Pretoria and South African National Biodiversity Institute provided financial support.

\section{REFERENCES}

ALADOS, C.L, NAVARRO, T. \& CABEZUDO, B. 1999. Tolerance assessment of Cistus ladanifer to serpentine soils by developmental stability analysis. Plant Ecology 143: 51-66.

BALKWILL. K. \& CAMPBELL-YOUNG, G.J. 2001. Taxonomic studies in the Acanthaceae: Peristrophe serpenticola-a new species from the Great Dyke, Zimbabwe. South African Journal of Science 97: 551-554.

BREDENKAMP, C. L. 2000. Ebenaceae (Dilleniidae-Theales). In O.A Leistner, Seed plants of southern Africa: families and genera Strelitzia 10: 245. National Botanical Institute, Pretoria.

CHUNG, M.G. \& KANG, S.S. 1996. Comparisons of genetic diversity in a narrow endemic, Impatiens hypophylla, and in its widespread congener. I. textori (Balsaminaceae). Nordic Journal of Botany 16: 359-364.

DE WINTER, B. 1963. Ebenaceae. Flora of southern Africa 26: 54-99. Botanical Research Institute, Pretoria

DIECKMANN, U. \& DOEBELI. M. 1999. On the origin of species by sympatric speciation. Nature 400: 354-357.

DYER, R.A. 1975. The genera of southern African fowering plants. vol. 1. Botanical Research Institute. Pretoria.

GRANT. V. 1992. Comments on the ecological species concept. Turon 41: $310-312$

HOLMGREN, P.K. HOLMGREN. N.H. \& BARLETT. L.C. 1990 Index herbariorum. Part 1. New York Botanical Gardens, Bronx. New York 
MENGES, E.S., MCINTYRE, P.J., FINER, M.S., GOSS, E. \& YAHR, R. 1999. Microhabitat of the narrow Florida scrub endemic Dicerandra christmanii, with comparisons to its congener $D$. frutescens. Journal of the Torrey Botanical Society 126: 24-31.

MOFFETT, R.O. 1999. A new species of Rhus (Anacardiaceae), endemic to serpentine near Barberton. Mpumalanga"(Eastern Transvaal), South Africa. Botanical Journal of the Linnean Society 130: $37-42$.

MÖNNIG, H.O. 1967. The Pedi. Van Schaik, Pretoria.

MUSTART P I COWLING, R M \& DUNNE, T.T. 1994. Reproductive traits of two closely related species-pairs on adjacent, different soil types in South African Fynbos. Vegetatio 111: 161-171.

PATON, C. 1998. The man who would be king. Sunday Times, November 15: 4, 5 .

REEVES, R.D. BROOKS, R.R. \& DUDLEY, T.R. 1983. Uptake of nickel by species of Alyssum. Bornmuellera, and other genera of the old world tribus Alysseae. Taxon 32: 184-192.

RETIEF, E. 1986. A new species of Euclea from the Transvaal. Bothalia 16: $228,229$.

RETIEF, E., SIEBERT, S.J. \& VAN WYK. A.E. 2001. A new species of Rhoicissus (Vitaceae) from Sekhukhuneland, South Africa. South African Journal of Botany 67: 230-234.

SCHMIDT, E., LÖTTER. M. \& MCCLELAND. W. 2002. Trees and shrubs of Mpumalanga and Kruger National Park: 7-22. Jacana. Johannesburg.

SIEBERT, S.J., VAN WYK, A.E. \& BREDENKAMP, G.J. 2001 Endemism in the flora of ultramafic areas of Sekhukhuneland South Africa. South African Journal of Science 97: 529-532.
SIEBERT, S.J., VAN WYK, A.E. \& BREDENKAMP, G.J. 2002a Vegetation ecology of Sekhukhuneland: Combretum hereroense-Grewia vernicosa Open Mountain Bushveld. South African Journal of Botany 68: 475-496.

SIEBERT. S.J., VAN WYK. A.E. \& BREDENKAMP, G.J. 2002b. Vegetation ecology of Sekhukhuneland: Kirkia wilmsiiTerminalia prunioides Closed Mountain Bushveld. South African Journal of Botany 68: 497-517.

VAN WYK. A.E. \& SMITH. G.F. 2001. Regions of floristic endemism in southern Africa. A review with emphasis on succulents: 126133. Umdaus Press, Hatfield. Pretoria.

VILJOEN. M.J. \& SCHÜRMAN. L.W. 1998. Platinum-group metals. In M.G.C. Wilson \& C.R. Anhaeusser. The mineral resources of South Africa. Council for Geoscience 16: 532-568. Council for Geoscience, Pretoria.

WALCK. J.L., BASKIN, J.M. \& BASKIN, C.C. 1999. Relative competitive abilities and growth characteristics of a narrowly endemic and a geographically widespread Solidago species (Asteraceae). American Journal of Botany 86: 820-828.

WHITE. F. 1977. The underground forests of Africa: a preliminary review. Gardens'Bulletin, Singapore 29: 57-71.

WHITE. F. 1983. 107. Ebenaceae. 2. Euclea. In E. Launert, Flora zambesiaca 7,1. Managing Committee, London.

WILD. H. 1965. The flora of the Great Dyke of southern Rhodesia with special reference to the serpentine soils. Kirkia 5: 49-86.

WILD, H. 1974. Variations in the serpentine floras of Rhodesia. Kirkia 9: 209-232. 